\title{
COMPARISON BETWEEN ENDOSCOPIC BRUSH CYTOLOGY PERFORMED BEFORE AND AFTER BILIARY STRICTURE DILATION FOR CANCER DETECTION
}

\author{
Laura Cotta ORNELLAS ${ }^{1}$, Gilda da Cunha SANTOS ${ }^{2}$, \\ Frank Shigueo NAKAO ${ }^{1}$ and Angelo Paulo FERRARI ${ }^{1}$
}

ABSTRACT - Background - Confirmation of malignancy within biliary strictures is endoscopically challenging. Dilation of strictures has been reported to enhance cytological diagnosis. Aim - To compare brush cytology results before and after biliary stricture dilation. Patients and Methods - Patients with extra-hepatic biliary stricture at endoscopic retrograde cholangiopancreatography were included in the study. Brushing was performed before and immediately after dilation using a 10 Fr dilating catheter. Cytology samples were classified as: negative for malignancy, presence of atypical cells, insufficient material, suspicious for malignancy or positive for malignancy. Final diagnosis was established by surgery, biopsy or followup. Results - Biliary brush cytology was performed in 50 patients, with an overall sensitivity of $40 \%$ and $27.5 \%$, before and after dilation, respectively. The combination of results increased cancer detection rate to $45 \%$. There were $5 / 50(10 \%)$ minor complications and one death related to the procedure. Conclusions - Brush cytology performed before biliary stricture dilation has a similar cancer detection rate to that following dilation, although the combination of results enhances sensitivity.

HEADINGS - Cytological techniques. Balloon dilatation. Cholangiopancreatography, endoscopic retrograde. Bile duct neoplasms. Pancreatic ducts.

\section{INTRODUCTION}

Patients with biliary obstruction usually undergo endoscopic retrograde cholangiopancreatography (ERCP) to confirm diagnosis and decompress the biliary tree. Many patients are considered unsuitable for surgery due to locally advanced disease, metastatic neoplasia or high surgical risk ${ }^{(2)}$. Accurate diagnosis is essential if surgery is to be considered or indeed for placement of self-expandable metallic stent in inoperable situations ${ }^{(4)}$. Furthermore, for considering patients to palliative chemo or radiotherapy a tissue or cytological diagnosis is often required ${ }^{(2)}$.

Tissue sampling at the time of ERCP is suboptimal. Ideally, a tissue sampling technique should have high sensitivity and specificity for cancer detection, besides being simple, safe and inexpensive. All methods currently available have high specificity, but low to moderate sensitivity ${ }^{(2)}$.

Biliary brush cytology has been the most frequently used and studied technique at ERCP. It was first described by OSNES et al. ${ }^{(17)}$ as a simple, safe and effective technique. Even though its specificity is close to $100 \%$, brush cytology sensitivity for cancer detection is modest, ranging from $30 \%$ to $70 \%$ in most published studies $^{(5,8,9,12,13,14,19,20,23,25,26)}$. Many centers perform dilation of biliary strictures on an inconsistent basis. Conceptually, endoscopic stricture dilation prior to brushing may increase the number of cells available for diagnosis, enhancing cytology yield ${ }^{(3)}$.

The aim of the present study was to compare the results of brushings performed before and after dilation of biliary strictures.

\section{PATIENTS AND METHODS}

Patients with extra-hepatic biliary stricture undergoing ERCP at "Hospital São Paulo", São Paulo, SP, Brazil, between April 1999 and January 2002 were included prospectively in this study. Exclusion criteria were the following: 1)

Department of Gastroenterology; ${ }^{2}$ Department of Pathology, Federal University of São Paulo, SP, Brazil.

Address for correspondence: Dr. Laura Cotta Ornellas - Rua Marechal Deodoro, 882 - apt. 901 - 36015-460 - Juiz de Fora, MG, Brazil. E-mail: lauraornellas@hotmail.com 
endoscopically visible periampullary tumors, 2) strictures that would not permit passage of guidewire, brush or dilator, 3) post-operative strictures and 4) previous brushing or placement of biliary stent.

Informed written consent was obtained before the procedure from all patients. This study was approved by the "Hospital São Paulo" Federal University of São Paulo Ethical Committee.

Following cannulation of the common bile duct, the stricture was identified and a guidewire was passed through it. Brushing was performed using a Geenen-type brush over the guidewire. Dilation was then performed using a $10 \mathrm{Fr}$ dilating catheter. Immediately following dilation, an identical brush was used to attain repeat cytology. Whenever endoscopic therapy was indicated, a stent was placed after brushing. Biliary sphincterotomy was performed in 18 patients $(36 \%)$ to facilitate bile duct access or stent placement.

Each brush was immediately smeared on six glass slides in the ERCP suite (three fixed in 95\% ethanol and three air dried). Samples were evaluated by an experienced cytopathologist who was blinded to the dilation status of each cytology sample. The specimens were stained with Papanicolaou and Giemsa techniques, and interpreted according to the characteristics established by RABINOVITZ et al. ${ }^{(22)}$, using standard cytological criteria for malignancy ${ }^{(11)}$. Cytology samples were classified as: 1) negative for malignancy, 2) presence of atypical cells, 3 ) insufficient specimen for diagnosis, 4) suspicious for malignancy, or 5) positive for malignancy.

For the purpose of statistical analysis, we grouped samples with insufficient material, negative for malignancy and atypical cells as negative, whilst specimens suspicious for malignancy and positive for malignancy were considered together.

The final diagnosis was confirmed following surgery, histopathological diagnosis of the lesion, radiological infiltration of adjacent organs or metastases, or after at least a 6-month follow-up.

Student's $t$ test or Fisher exact test were used to compare variables between the groups with malignant neoplasia and inflammatory disease. Sensitivity, specificity, positive and negative predictive values and diagnostic accuracy were determined for each test. The results were compared using the McNemar test. A $P$ value of less than 0.05 was considered statistically significant.

\section{RESULTS}

Fifty consecutive patients with biliary strictures having undergone ERCP and brush cytology were prospectively enrolled. Among these, 40 patients were confirmed to have malignant neoplasia: pancreatic adenocarcinoma (18), cholangiocarcinoma (17), gallbladder cancer (2), metastases (2) and neuroendocrine carcinoma of the pancreas (1). Inflammatory disease was observed after a mean follow-up of 29 months (range 17-39 months) in 10 patients: chronic pancreatitis (6) and inflammatory stenosis secondary to bile duct stones (4).

Patients with malignant neoplasia were significantly $(P=0.02)$ older (mean age $=64$ years, range $42-82$ years) than those with inflammatory disease (mean age $=54$ years, range 39-68 years).
The results of biliary brush cytology obtained from the 50 patients before and immediately after stricture dilation are shown in Table 1. There was no statistically significant difference between the results obtained before and after dilation $(P=0.18)$, and those obtained before and combining pre- and post-dilation brushings $(P=0.50)$.

TABLE 1 - Results of biliary brush cytology obtained before and/or after stricture dilation in 50 patients (expressed in $\%$ and $95 \%$ confidence interval)

\begin{tabular}{lccc}
\hline & Predilation & Postdilation & Combined \\
\hline Sensitivity & $40.0(24.8-55.2)$ & $27.5(13.7-41.3)$ & $45.0(29.6-60.4)$ \\
Specificity & $100.0(100.0-100.0)$ & $100.0(100.0-100.0)$ & $100.0(100.0-100.0)$ \\
PPV & $100.0(100.0-100.0)$ & $100.0(100.0-100.0)$ & $100.0(100.0-100.0)$ \\
NPV & $29.4(14.1-44.7)$ & $25.6(11.9-39.3)$ & $31.3(15.2-47.4)$ \\
Accuracy & $52.0(38.2-65.8)$ & $42.0(28.3-55.7)$ & $56.0(42.2-69.8)$ \\
\hline
\end{tabular}

$\mathrm{PPV}=$ positive predictive value; $\mathrm{NPV}=$ negative predictive value

Cytology samples classified as positive and suspicious for malignancy were found in 5 and 11 patients before dilation, 3 and 8 after dilation, 7 and 11 cases when both pre- and postdilation samples were combined, respectively. Cytology specimens were classified as insufficient for diagnosis in $14(28 \%)$ patients before dilation, $18(36 \%)$ after dilation and in $9(18 \%)$ patients when combined (not significant).

When the results of pre- and post-dilation brushings were combined, brush cytology was more sensitive for cholangiocarcinoma $(52.9 \%)$ than pancreatic carcinoma $(33.3 \%)$, but there was no statistically significance. In view of the small number of patients a type II error can not be excluded.

Complications were observed in six cases: acute pancreatitis (two), early stent occlusion (two), bleeding following precut sphincterotomy (one). One patient with previous Billroth II gastrectomy and advanced cholangiocarcinoma died 4 days after ERCP due to perforation of the afferent loop.

\section{DISCUSSION}

Imaging studies (CT, MRI and EUS) are able to diagnose biliary obstruction, but they often can not confirm the etiology ${ }^{(1,10,18)}$. Although EUS represents a major advance in the evaluation of biliary strictures, current limitations have to be emphasized such as: technical sophistication, requirement of significant expertise to accurate image interpretation, high cost, potential complications, lack of facility for therapeutic intervention and difficulty in differentiation between benign and malignant stricture ${ }^{(15)}$.

Reliable differentiation between benign and malignant etiology remains a challenge. Acquiring tissue from such lesions during ERCP is the classical approach since affected patients are commonly evaluated and primarily treated during $\mathrm{ERCP}^{(4)}$.

Features that affect cancer detection rate on cytology samples are adequacy and processing, slides interpretation and tumor type $^{(2)}$. Some previous studies ${ }^{(13,14,19,24)}$ excluded patients with insufficient cellularity, so they showed a higher sensitivity for cancer detection than they would have achieved if all cases had been analyzed. If patients with inadequate specimens were 
excluded from our data, the sensitivity for cancer before stricture dilation, immediately after and combining pre- and post-dilation would increase to $59.3 \%, 44 \%$ and $56.3 \%$, respectively.

Surprisingly, the present study shows that brushings performed after dilating the biliary epithelium using a $10 \mathrm{Fr}$ dilation catheter have more inadequate samples for cytological analysis, although the difference is not significant. This finding may be explained by the presence of more clots or degenerate cells after duct dilation. Nevertheless, repeated brushings not only decreased the percentage of cases with insufficient samples from $28 \%$ to $18 \%$, but also improved cancer detection rate from $40 \%$ to $45 \%$.

MOHANDAS et al. ${ }^{(16)}$ demonstrated that dilating a malignant stricture using a $10 \mathrm{Fr}$ catheter before bile aspiration enhanced cancer detection rate in comparison with a non dilation group $(63.3 \%$ vs. $26.6 \%)$. Similarly, FARRELL et al..$^{(4)}$ evaluated the sensitivity for malignancy of brush cytology after aggressive stricture manipulation by combined dilation up to $10 \mathrm{Fr}$ and endoscopic needle aspiration. This sequence of procedures significantly increased cancer detection rate $(85 \%)$ compared with brushing alone $(57 \%)$. De BELLIS et al. ${ }^{(3)}$ investigated the sensitivity of brush cytology after dilation in a series of 139 patients with suspected malignant stricture. Cancer detection rate before dilation $(34.5 \%)$ was similar to post-dilation rate $(31 \%)$. Subgroup analysis revealed no difference in sensitivity after catheter $(34.7 \%)$ or balloon $(27.7 \%)$ dilation. The authors concluded that the diagnostic yield increased from $34.5 \%$ to $44 \%(P<0.01)$ when the results for the two consecutive brushings were combined.

Some cases of insufficient samples would have been avoided if the brush were not pulled out of its sheath before the specimens were smeared on glass slides. The technique used in this study may result in cellular loss within the sheath, but this is still a point of controversy. We did use such approach in order to maintain access to the proximal bile duct. Cancer detection rate for biliary brush cytology in the present study was higher for cholangiocarcinoma $(52.9 \%)$ than for pancreatic carcinoma $(33.3 \%)$, similar to the literature ${ }^{(3,8,14,19,21,25,26)}$. Pancreatic tumors or metastases, which extrinsically compress the bile duct or manifest submucosal growth, are unlikely to be detected by brushing during early-stage disease. Cholangiocarcinomas, which originate from biliary epithelium, may be more amenable to cytological diagnosis ${ }^{(6,7)}$.

In conclusion, sensitivity for malignancy of biliary brushings performed before and after stricture dilation are similar, although combination of results increases sensitivity and diagnostic accuracy.

\section{ACKNOWLEDGMENT}

This study was partially sponsored by CNPq and FAPESP (process \# 02/1850-3).

Ornellas LC, Santos GC, Nakao FS, Ferrari AP. Comparação entre citologia por escovado endoscópico realizada antes e depois da dilatação das estenoses biliares para detecção de câncer. Arq Gastroenterol. 2006;43(1):20-3.

RESUMO - Racional - A citologia por escovado apresenta baixa sensibilidade na detecção de câncer em estenoses biliares, mas manipulação endoscópica prévia poderia aumentar a esfoliação de células tumorais. Objetivo - Comparar os resultados dos escovados obtidos antes e depois da dilatação de estenoses biliares. Pacientes $\boldsymbol{e}$ Métodos - Pacientes com estenose biliar extra-hepática diagnosticada durante colangiopancreatografia endoscópica retrógada foram submetidos a citologia por escovado. Em seguida, a estenose foi dilatada com cateter de 10 French e o escovado foi repetido. A citologia foi classificada como: negativa para malignidade, presença de células atípicas, material insuficiente, suspeita para malignidade ou positiva para malignidade. O diagnóstico final foi determinado por cirurgia, biopsia ou acompanhamento clínico. Resultados - O escovado biliar foi obtido em 50 pacientes, com sensibilidade de 40\% e 27,5\%, respectivamente, antes e depois da dilatação. A combinação dos resultados aumentou a positividade para 45\%. Houve 5/50 (10\%) complicações menores e um óbito relacionado ao procedimento. Conclusões - A positividade do escovado biliar realizado antes de dilatar a estenose para detecção de neoplasia maligna é semelhante àquela obtida depois da dilatação, embora a combinação dos resultados aumente a sensibilidade.

DESCRITORES - Técnicas citológicas. Dilatação com balão. Pancreatocolangiografia retrógrada endoscópica. Neoplasia das vias biliares. Ductos pancreáticos. 


\section{REFERENCES}

1. Barish MA, Yucel EK, Ferrucci JT. Magnetic resonance cholangiopancreatography. N Engl J Med. 1999;341:258-64.

2. De Bellis M, Sherman S, Fogel EL, Cramer H, Chappo J, McHenry L Jr, Watkins JL, Lehman GA. Tissue sampling at ERCP in suspected malignant biliary strictures (Part 1). Gastrointest Endosc. 2002;56:552-61.

3. De Bellis M, Fogel EL, Sherman S, Watkins JL, Chappo J, Younger C, Cramer H, Lehman GA. Influence of stricture dilation and repeat brushing on the cancer detection rate of brush cytology in the evaluation of malignant biliary obstruction. Gastrointest Endosc. 2003;58:176-82.

4. Farrell RJ, Jain AK, Brandwein SL, Wang H, Chuttani R, Pleskow DK. The combination of stricture dilation, endoscopic needle aspiration, and biliary brushings significantly improves diagnostic yield from malignant bile duct strictures. Gastrointest Endosc. 2001;54:587-94.

5. Ferrari Jr AP, Lichtenstein DR, Slivka A, Chang C,Carr-Locke DL. Brush cytology during ERCP for the diagnosis of biliary and pancreatic malignancies. Gastrointest Endosc. 1994;40:140-5.

6. Fogel EL, Sherman S. How to improve the accuracy of diagnosis of malignant biliary strictures. Endoscopy. 1999;31:758-60.

7. Foutch PG. Diagnosis of cancer by cytologic methods performed during ERCP. Gastrointest Endosc. 1994;40:249-52.

8. Glasbrenner B, Ardan M, Boeck W, Preclik G, Moller P, Adler G. Prospective evaluation of brush cytology of biliary strictures during endoscopic retrograde cholangiopancreatography. Endoscopy. 1999;31:712-7.

9. Howell DA, Parsons WG, Jones MA, Bosco JJ, Hanson BL. Complete tissue sampling of biliary strictures at ERCP using a new device. Gastrointest Endosc. 1996;43:498-502.

10. Hunt GC, Faigel DO. Assessment of EUS for diagnosing, staging, and determining resectability of pancreatic cancer: a review. Gastrointest Endosc. 2002;55:232-7.

11. Kline TS. Pancreas. In: Handbook of fine needle aspiration biopsy cytology. $2^{\text {nd }}$ ed. New York: Churchill Livingstone; 1988. p. 317

12. Lee JG, Leung JW, Baillie J, Layfield LJ, Cotton PB. Benign, dysplastic, or malignant - making sense of endoscopic bile duct brush cytology: results in 149 consecutive patients. Am J Gastroenterol. 1995;90:722-6.

13. Macken E, Drijkoningen M, Van Aken E, Van Steenbergen W. Brush cytology of ductal strictures during ERCP. Acta Gastroenterol Belg. 2000;63:254-9.

14. Mansfield JC, Griffin SM, Wadehra V, Matthewson K. A prospective evaluation of cytology from biliary strictures. Gut. 1997;40:671-7.

15. Mehta SN, Barkun A. The role of endoscopic ultrasonography in biliary tract disease, obstructive jaundice. Gastrointest Endosc. 1996;43:534-5.
16. Mohandas KM, Swaroop VS, Gullar SU, Dave UR, Jagannath P, DeSouza LJ. Diagnosis of malignant obstructive jaundice by bile cytology: results improved by dilating the bile duct strictures. Gastrointest Endosc. 1994;40:150-4.

17. Osnes M, Serck-Hanssen A, Myren J. Endoscopic retrograde brush cytology (ERBC) of the biliary and pancreatic ducts. Scand J Gastroenterol. 1975;10:829-31.

18. Pasanen PA, Partanen KP, Pikkarainen PH, Alhava EM, Janatuinen EK, Pirinen AE. A comparison of ultrasound, computed tomography and endoscopic retrograde cholangiopancreatography in the differential diagnosis of benign and malignant jaundice and cholestasis. Eur J Surg. 1993;159:23-9.

19. Ponchon T, Gagnon P, Berger F, Labadie M, Liaras A, Chavaillon A, Bory R. Value of endobiliary brush cytology and biopsies for the diagnosis of malignant bile duct stenosis: results of a prospective study. Gastrointest Endosc. 1995;42:565-72.

20. Pugliese V, Conio M, Nicolo G, Saccomanno S, Gatteschi B. Endoscopic retrograde forceps biopsy and brush cytology of biliary strictures: a prospective study. Gastrointest Endosc 1995;42:520-6.

21. Pugliese V, Antonelli G, Vincenti M, Gatteschi B. Endoductal tissue sampling of biliary strictures through endoscopic retrograde cholangiopan creatography (ERCP). Tumori. 1997;83:698-702

22. Rabinovitz M, Zajko AB, Hassanein T, Shetty B, Bron KM, Schade RR, Gavaler JS, Block G, Van Thiel DH, Dekker A. Diagnostic value of brush cytology in the diagnosis of bile duct carcinoma: a study in 65 patients with bile duct strictures. Hepatology. $1990 ; 12: 747-52$

23. Schoefl R, Haefner M, Wrba F, Pfeffel F, Stain C, Poetzi R, Gangl A. Forceps biopsy and brush cytology during endoscopic retrograde cholangiopancreatography for the diagnosis of biliary stenoses. Scand J Gastroenterol. 1997;32:363-8.

24. Stewart CJ, Mills PR, Carter R, O'Donohue J, Fullarton G, Imrie CW, Murray WR Brush cytology in the assessment of pancreatico-biliary strictures: a review of 406 cases. J Clin Pathol. 2001;54:449-55.

25. Sugiyama M, Atomi Y, Wada N, Kuroda A, Muto T. Endoscopic transpapillary bile duct biopsy without sphincterotomy for diagnosing biliary strictures: a prospective comparative study with bile and brush cytology. Am J Gastroenterol. 1996;91:4657

26. Vandervoort J, Soetikno RM, Montes H, Lichtenstein DR, Van Dam J, Ruymann FW, Cibas ES, Carr-Locke DL. Accuracy and complication rate of brush cytology from bile duct versus pancreatic duct. Gastrointest Endosc. 1999;49:322-7.

Recebido em 11/11/2004 Aprovado em 23/8/2005. 